Siti Badriyah Islamiyatun, Sri Hermuningsih, Agus Dwi Cahya / Pengaruh Profitabilitas, Likuiditas Dan Solvabilitas Terhadap Kondisi Financial Distress

\title{
PENGARUH PROFITABILITAS, LIKUIDITAS DAN SOLVABILITAS TERHADAP KONDISI FINANCIAL DISTRESS
}

\author{
Siti Badriyah Islamiyatun \\ Universitas Sarjanawiyata Tamansiswa \\ Badriyahislam1@gmail.com \\ Sri Hermuningsih \\ Universitas Sarjanawiyata Tamansiswa \\ hermun_feust@yahoo.co.id \\ Agus Dwi Cahya \\ Universitas Sarjanawiyata Tamansiswa \\ agusdc@ustjogja.ac.id
}

\begin{abstract}
The study was conducted to determine the effect of profitability, liquidity and solvency conditions financial distress in companies listed in the LQ 45 index for the 2015-2019 period. The type of research used is quantitative research. The population in this study are companies listed in the LQ 45 index for the 2015-2019 period, with a sample of 20 companies. The sampling technique used is purposive sampling. The data analysis technique used descriptive statistics, classical assumption test, and regression test. The results showed that the profitability ratio (return on assets) and liquidity ratio (current ratio) had a positive and significant effect on conditions financial distress, the solvency ratio (debt ratio) had a negative and significant effect on conditions financial distress.
\end{abstract}

Keyword: profitability, liquidity, solvabiltity, financial distress.

\section{PENDAHULUAN}

Kondisi ekonomi suatu negara mempengaruhi kinerja keuangan perusahaan yang berada di negara tersebut, baik perusahaan besar maupun perusahaan kecil (Liana 2014). Meskipun ekonomi negara berada pada kondisi yang stabil, tidak menutup kemungkinan perusahaan akan mengalami financial distress. Financial distress dapat dikatakan sebagai kondisi keuangan perusahaan dalam keadaan tidak sehat atau mengalami kesulitan. Semua perusahaan memiliki kemungkinan mengalami kondisi kesulitan keuangan, perusahaan yang terdaftar dalam Bursa Efek Indonesia pun dapat mengalami kesulitan keuangan. Apabila perusahaan terindikasi mengalami financial distress, pihak manajemen dapat melakukan suatu tindakan yang tepat untuk mengatasi kondisi tersebut agar tidak sampai pada masalah kebangkrutan.

Menurut (Hapsari 2012) dengan cara menganalisis rasio-rasio keuangan yang ada dalam laporan keuangan suatu perusahaan dapat digunakan untuk melihat kondisi financial distress perusahaan, kemudian dari hasil analisis tersebut dapat digunakan oleh perusahaan maupun investor untuk menentukan kebijakan.

Penelitian ini menggunakan rasio profitabilitas, rasio likuiditas dan rasio solvabilitas untuk mengukur kondisi financial distress yang terjadi pada perusahaan yang terdaftar dalam indeks LQ 45. 
Siti Badriyah Islamiyatun, Sri Hermuningsih, Agus Dwi Cahya / Pengaruh Profitabilitas, Likuiditas Dan Solvabilitas Terhadap Kondisi Financial Distress

\section{TINJAUAN PUSTAKA DAN PENGEMBANGAN HIPOTESIS}

Pengertian Financial Distress.

Luciana dalam Gobenvy (2014) mengartikan financial distress sebagai kondisi perusahaan sedang mengalami penurunan kinerja keuangan.

\section{Faktor Penyebab Financial Distress}

Menurut Janch \& Glueck dalam Andre (2014), Secara garis besar faktor faktor penyebab kesulitan keuangan/financial distress dibagi menjadi tiga, yaitu:

Faktor Umum :

1) Sektor Ekonomi

Faktor Faktor penyebab financial distress dari sektor ekonomi yaitu adanya gejala inflasi dan deflasi dalam harga barang dan jasa, kebijakan keuangan, dan suku bunga.

2) Sektor Sosial

Faktor sosial seperti perubahan gaya hidup masyarakat dapat mempengaruhi produksi barang/jasa yang dihasilkan oleh perusahaan.

3) Sektor Teknologi

4) Sektor Pemerintah

Penyebab financial distress perusahaan dari sektor pemerintah bisa terjadi apabila kebijakan yang diambil pemerintah memberatkan perusahaan seperti kebijakan tarif ekspor impor.

Faktor Eksternal Perusahaan :

1) Sektor Pelanggan

Pentingnya kemampuan perusahaan dalam mengidentifikasi sifat konsumen agar dapat menghindari kehilangan konsumen, selain itu juga bisa menjadi peluang-peluang menemukan konsumen baru.

2) Sektor Pemasok

Kerjasama antara perusahaan dengan pemasok harus terjaga dengan baik, karena pemasok memiliki kekuatan dalam masalah harga yang juga berpengaruh terhadap keuntungan perusahaan nantinya.
3) Sektor Pesaing

Kekuatan pesaing mempengaruhi jumlah konsumen dan pendapatan yang diterima perusahaan. Untuk itu perusahaan harut tetap memperhatikan perusahaan pesaing.

Faktor Internal Perusahaan :

Penyebab terjadinya financial distress dari internal perusahaan dapat disebebkan dari keputusan dan kebijakan yang tidak tepat dimasa lalu, dan kegagalan manajemen untuk melakukan tindakan yang tepat pada saat yang diperlukan.

\section{Metode Analisis Financial Distress}

Financial distress diukur dengan persamaan Altman Z-score dengan rumus sebagai berikut:

$\mathrm{Z}=1.2 \mathrm{X} 1+1.4 \mathrm{X} 2+3.3 \mathrm{X} 3+0.6 \mathrm{X} 4+$ $1.0 \times 5$.

\section{Pengaruh Rasio Profitabilitas Terhadap Financial Distress}

Rasio profitabilitas diukur dengan return on asset. Rasio return on asset yang tinggi mengindikasikan kemampuan perusahaan memperoleh keuntungan cukup baik. Semakin tinggi nilai return on asset kemungkinan perusahaan mengalami financial distress semakin kecil.

Didukung oleh penelitian (Masitoh 2017). Rasio profitabilitas berpengaruh positif terhadap financial distress. Ini berarti bahwa semakin merugi perusahaan maka semakin tinggi potensi perusahaan mengalami financial distress. Berdasarkan penjelasan tersebut maka hipotesis dalam penelitian ini sebagai berikut:

H1: Rasio profitabilitas berpengaruh terhadap financial distress

\section{Pengaruh Rasio Likuiditas Terhadap Financial Distress}

Rasio likuiditas diukur dengan current ratio mengukur kemampuan perusahaan memenuhi hutang jangka pendeknya dengan menggunakan aktiva 
lancarnya. Semakin besar rasio likuiditas maka semakin kecil kemungkinan perusahaan mengalami financial distress (Imam Mas'ud 2012).

Penelitian yang dilakukan oleh (Yudiawati and Indriani 2016) menunjukkan bahwa rasio likuiditas (current ratio) berpengaruh positif signifikan dalam memprediksi financial distress. Hal tersebut menunjukkan bahwa semakin tinggi current ratio semakin meningkatkan Current Asset, sehingga menurunkan kinerja perusahaan yang memungkinkan terjadinya financial distress semakin tinggi.

H2: Rasio likuiditas berpengaruh terhadap kondisi financial distress

\section{Pengaruh Rasio Solvabilitas Terhadap Financial Distress}

Rasio solvabilitas digunakan untuk mengukur presentase besarnya dana yang berasal dari hutang. Penggunaan utang

\section{METODE PENELITIAN}

\section{Populasi dan Sampel}

Populasi penelitian ini adalah perusahaan yang terdaftar dalam indeks LQ 45 periode yang terlalu tinggi dapat mengakibatkan perusahaan kesulitan untuk melunasi utang yang dimilikinya. Artinya jika kondisi tersebut berlangsung dalam jangka waktu yang lama, maka bisa dikatakan rasio Solvabilitas akan semakin tinggi dan perusahaan diprediksi akan mengalami financial distress (Marfungatun 2017).

Didukung oleh penelitian yang dilakukan (Chrissentia and Syarief 2018). yang menyatakan bahwa Solvabilitas berpengaruh signifikan terhadap financial distress. Artinya, dalam menjalankan operasionalnya, perusahaan tidak banyak menggunakan pendanaan yang berasal dari utang, sehingga dengan utang yang rendah maka kemungkinan gagal bayar perusahaan juga rendah. Dengan demikian, financial distress semakin kecil terjadi.

H3: Rasio Solvabilitas berpengaruh terhadap kondisi financial distress

2015-2019. Sampel yang digunakan dalam penelitian ini adalah 20 perusahaan yang terdaftar dalam indeks LQ 45

Tabel 1 Sampel yang digunakan

\begin{tabular}{llc}
\hline No & \multicolumn{1}{c}{ Keterangan } & $\begin{array}{c}\text { Jumlah } \\
\text { Perusahaan }\end{array}$ \\
\hline 1. & $\begin{array}{l}\text { Perusahaan yang terdaftar dalam indeks LQ 45 periode 2015- } \\
2019\end{array}$ & 67 \\
\hline 2. & $\begin{array}{l}\text { Perusahaan yang tidak kontinu masuk dalam indeks LQ 45 } \\
\text { periode 2015-2019 }\end{array}$ & $(40)$ \\
\hline 3. & Perusahaan sektor keuangan & $(5)$ \\
\hline 4. & $\begin{array}{l}\text { Perusahaan yang mempublikasikan laporan keuangan dinyatakan } \\
\text { dalam Dolar AS }\end{array}$ & $(2)$ \\
\hline \multicolumn{1}{c}{ Jumlah sampel perusahaan } & 20 \\
\hline \multicolumn{1}{c}{ Total jumlah pengamatan selama 5 tahun } \\
\hline
\end{tabular}

\section{Metode Analisis Data}

Metode analisis data yang digunakan dalam penelitian ini yaitu uji statistik deskriptif, uji asumsi klasik dan uji regresi.
Uji Statistik Deskriptif

Statistik deskriptif digunakan untuk mengetahui gambaran umum tentang data penelitian dan hubungan antara 
Siti Badriyah Islamiyatun, Sri Hermuningsih, Agus Dwi Cahya / Pengaruh Profitabilitas, Likuiditas Dan Solvabilitas Terhadap Kondisi Financial Distress

variabel-variabel yang digunakan dalam penelitian.

Uji Asumsi Klasik

Uji asumsi klasik dilakukan dengan tujuan untuk mengetahui dan menguji kelayakan atas model regresi yang digunakan dalam suatu penelitian.

Uji Regresi

a. Uji Koefisien Determinasi

Koefisien determinasi $\left(\mathrm{R}^{2}\right)$ pada intinya mengukur seberapa jauh kemampuan model dalam menerangkan variasi variabel dependen.

b. Analisis Regresi Linier Berganda Analisis regresi linier berganda untuk menjawab permasalahan penelitian, yaitu pengaruh profitabilitas (return on assets), likuiditas (current ratio), dan solvabilitas (debt ratio) terhadap financial distress perusahaan.

Persamaan analisis regresi linier berganda adalah sebagai berikut:

$\mathrm{Y}=\mathrm{a}+\mathrm{b} 1 \mathrm{X} 1+\mathrm{b} 2 \mathrm{X} 2+\mathrm{b} 3 \mathrm{X} 3+\mathrm{e}$

c. Uji t

Pengujian koefisien regresi dilakukan untuk menguji seberapa jauh semua variabel bebas (independen) yang dimasukkan dalam model mempunyai pengaruh terhadap variabel terikat (dependen).

\section{HASIL DAN PEMBAHASAN}

\section{Uji statistik deskriptif}

Tabel 1. Hasil uji ststistik deskriptif

\begin{tabular}{lccccc}
\hline \multicolumn{7}{c}{ Descriptive Statistics } \\
\hline & $\mathrm{N}$ & Minimum & maximum & Mean & Std. Deviation \\
Profitabilitas & 100 &, 01 &, 46 &, 1203 &, 10322 \\
Likuiditas & 100 &, 28 & 7,31 & 1,9979 & 1,24358 \\
Solvabilitas & 100 &, 13 &, 77 &, 4605 &, 18509 \\
Financial_Distress & 100 &, 20 & 6,59 & 3,1388 & 1,64177 \\
Valid N (listwise) & 100 & \multicolumn{7}{c}{} & \\
\hline
\end{tabular}

\section{Uji asumsi klasik}

Tabel 2. Uji Normalitas

\begin{tabular}{|c|c|c|}
\hline \multicolumn{3}{|c|}{ One-Sample Kolmogorov-Smirnov Test } \\
\hline & & $\begin{array}{l}\text { Unstandardized } \\
\text { Residual }\end{array}$ \\
\hline \multicolumn{2}{|l|}{$\mathrm{N}$} & 100 \\
\hline \multirow[t]{2}{*}{ Normal Parameters ${ }^{\mathrm{a}, \mathrm{b}}$} & Mean & $0 \mathrm{E}-7$ \\
\hline & Std. Deviation & ,65068883 \\
\hline \multirow{3}{*}{$\begin{array}{l}\text { Most Extreme } \\
\text { Differences }\end{array}$} & Absolute &, 102 \\
\hline & Positive & ,077 \\
\hline & Negative &,- 102 \\
\hline \multicolumn{2}{|l|}{ Kolmogorov-Smirnov Z } & 1,017 \\
\hline
\end{tabular}


Siti Badriyah Islamiyatun, Sri Hermuningsih, Agus Dwi Cahya / Pengaruh Profitabilitas, Likuiditas Dan Solvabilitas Terhadap Kondisi Financial Distress

\begin{tabular}{l|l}
\hline Asymp. Sig. (2-tailed) &, 252 \\
\hline a. Test distribution is Normal. & \\
\hline b. Calculated from data. & \\
\hline
\end{tabular}

Berdasarkan hasil output pengujian SPSS pada tabel diatas, diperoleh nilai signifikan sebesar $0,252>0,05$, maka dapat disimpulkan bahwa data pada penelitian tersebut berdistribusi normal yang artinya uji normalitas terpenuhi.

Tabel 3. Uji Multikolinearitas

\begin{tabular}{|c|c|c|c|}
\hline \multicolumn{4}{|c|}{ Coefficients $^{\mathrm{a}}$} \\
\hline & \multirow[t]{2}{*}{ Model } & \multicolumn{2}{|c|}{ Collinearity Statistics } \\
\hline & & Tolerance & VIF \\
\hline \multirow[t]{3}{*}{1} & Profitabilitas & ,992 & 1,009 \\
\hline & Likuiditas & ,419 & 2,387 \\
\hline & Solvabilitas & ,419 & 2,389 \\
\hline
\end{tabular}

Hasil uji multikolinearitas menunjukkan bahwa nilai VIF variabel penelitian tidak lebih dari angka 10. Dari angka tersebut dapat disimpulkan bahwa tidak ada multikolinearitas antar variabel independen dalam model regresi.

Tabel 4. Uji Heterokedastisitas

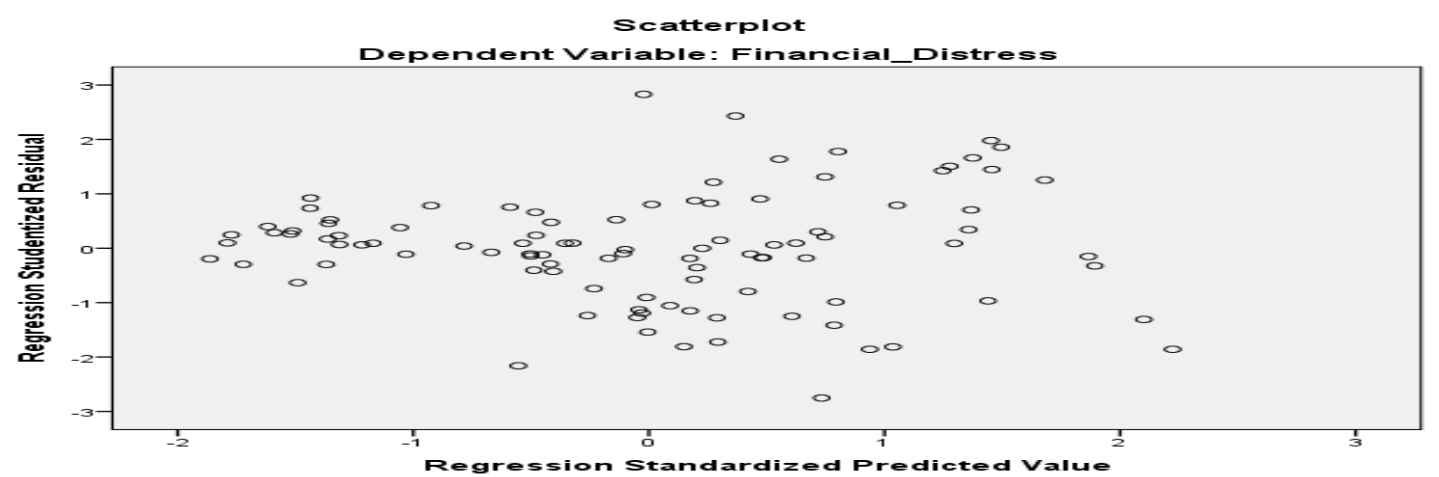

Terlihat bahwa titik-titik menyebar diatas dan dibawah angka nol pada sumbu Y, hal ini mengindikasikan bahwa tidak terjadi ganguan heterokedastisitas pada model regresi.

Tabel 5. Uji Autokorelasi

\begin{tabular}{l|c|r|r|r|r}
\hline \multicolumn{9}{c}{ Model Summary } \\
\hline Model & $\mathrm{R}$ & $\begin{array}{c}\mathrm{R} \\
\text { Square }\end{array}$ & $\begin{array}{c}\text { Adjusted } \\
\text { R Square }\end{array}$ & $\begin{array}{r}\text { Std. Error of } \\
\text { the Estimate }\end{array}$ & Durbin-Watson \\
\hline 1 &, $920^{\mathrm{a}}$ &, 846 &, 841 &, 65467 & 1,869 \\
\hline
\end{tabular}


Siti Badriyah Islamiyatun, Sri Hermuningsih, Agus Dwi Cahya / Pengaruh Profitabilitas, Likuiditas Dan Solvabilitas Terhadap Kondisi Financial Distress

a. Predictors: (Constant), Solvabilitas, Profitabilitas, Likuiditas

b. Dependent Variable: Financial_Distress

Dengan melihat kriteria pada pedoman

Durbin-Watson maka diperoleh nilai

$1,7364<1,869<2,2636$, dari hasil sebagai berikut : du $<\mathrm{dw}<4-\mathrm{du}$ atau tersebut dapat diambil keputusan bahwa tidak terdapat gejala autokorelasi.

Hasil uji Koefisien determinasi dapat dilihat berikut:

Tabel 6. Hasil Uji Koefisien determinasi

\begin{tabular}{l|c|c|c|c|c}
\hline \multicolumn{6}{c}{ Model Summary $^{\mathbf{b}}$} \\
\hline Model & $\mathrm{R}$ & R Square & $\begin{array}{l}\text { Adjusted } \\
\text { R Square }\end{array}$ & $\begin{array}{c}\text { Std. Error of } \\
\text { the Estimate }\end{array}$ & $\begin{array}{c}\text { Durbin- } \\
\text { Watson }\end{array}$ \\
\hline 1 &, $920^{\mathrm{a}}$ &, 846 &, 841 &, 65467 & 1,869 \\
\hline \multicolumn{6}{l}{ a. Predictors: (Constant), Solvabilitas, Profitabilitas, Likuiditas } \\
\hline
\end{tabular}

Berdasarkan hasil uji koefisien determinas pada Tabel 6, dapat diketahui Nilai Adjusted R Aquare sebesar 0,841 menunjukkan bahwa $84,1 \%$ variasi variabel dependen dapat dijelaskan oleh variabel independen yang artinya rata-rata setiap variabel independen mampu menjelaskan 28\%. Sedangkan sisanya sebesar 15,9\% dipengaruhi oleh variabel lain yang tidak diteliti. Standar error of the estimate sebesar $0,65467<1,25222$ (standar deviasi financial distress) berarti model regresi semakin tepat dalam memprediksi variabel dependen.

Tabel 7. Hasil Uji t

\begin{tabular}{|c|c|c|c|c|c|c|}
\hline \multicolumn{7}{|c|}{ Coefficients $^{a}$} \\
\hline \multirow{2}{*}{\multicolumn{2}{|c|}{ Model }} & \multicolumn{2}{|c|}{$\begin{array}{c}\text { Unstandardized } \\
\text { Coefficients }\end{array}$} & \multirow{2}{*}{$\begin{array}{c}\begin{array}{c}\text { Standardized } \\
\text { Coefficients }\end{array} \\
\text { Beta } \\
\end{array}$} & \multirow[t]{2}{*}{$\mathrm{t}$} & \multirow[t]{2}{*}{ Sig. } \\
\hline & & B & Std. Error & & & \\
\hline \multirow[t]{4}{*}{1} & (Constant) & 3,556 & ,411 & & 8,659 & 000 \\
\hline & Profitabilitas & 9,978 &, 640 & ,627 & 15,584 &, 000 \\
\hline & Likuiditas & ,237 &, 082 &, 180 & 2,908 &, 005 \\
\hline & Solvabilitas & $-4,541$ &, 548 &,- 513 & $-8,284$ & ,000 \\
\hline
\end{tabular}

Berdasarkan tabel 7, dapat dilihat koefisien untuk perasamaan regresi pertama dari penelitian ini, yang dapat disusun dalam persamaan matematis sebagai berikut:

$\mathrm{Y}=3,556+9,978 \mathrm{X} 1+0.237 \mathrm{X} 2-$ $4,541 \mathrm{X} 3+\mathrm{e}$
Berdasarkan hasil uji t pada Tabel 7, dapat diketahui pengaruh masing-masing variabel independent yaitu profitabilitas (return on asset), likuiditas (current ratio), dan solvabilitas (debt ratio) terhadap financial distress sebagai berikut: 
Siti Badriyah Islamiyatun, Sri Hermuningsih, Agus Dwi Cahya / Pengaruh Profitabilitas, Likuiditas Dan Solvabilitas Terhadap Kondisi Financial Distress

Profitabilitas memiliki koefisien sebesar 9,978 dengan tingkat signifikansi lebih kecil dari 0,05 yaitu 0,000 . Nilai signifikansi dan koefisien tersebut menunjukkan bahwa rasio profitabilitas (return on assets) berpengaruh positif dan signifikan kuat terhadap terjadinya financial distress pada perusahaan yang terdaftar dalam indeks LQ 45. Likuiditas memiliki koefisien sebesar 0,237 dengan tingkat signifikansi lebih kecil dari 0,05 yaitu 0,005. Nilai signifikansi dan koefisien tersebut menunjukkan bahwa rasio likuiditas (current ratio) berpengaruh positif dan signifikan kuat terhadap terjadinya financial distress pada perusahaan yang terdaftar dalam indeks LQ 45. bahwa solvabilitas memiliki koefisien sebesar -4,541 dengan tingkat signifikansi lebih kecil dari 0,05 yaitu 0,000 . Nilai signifikansi dan koefisien tersebut menunjukkan bahwa rasio solvabilitas (debt ratio) berpengaruh negatif dan signifikan kuat terhadap terjadinya financial distress pada perusahaan yang terdaftar dalam indeks LQ 45.

\section{KESIMPULAN}

Hasil analisis dalam penelitian ini menunjukkan bahwa Rasio profitabilitas berpengaruh positif dan signifikan kuat dalam memprediksi kondisi financial distress pada perusahaan yang terdaftar dalam indeks LQ 45 periode 2015-2019. Rasio likuiditas berpengaruh positif dan signifikan kuat dalam memprediksi kondisi financial distress pada perusahaan yang terdaftar dalam indeks LQ 45 periode 2015-2019. Rasio solvabilitas berpengaruh negatif dan signifikan kuat dalam memprediksi kondisi financial distress pada perusahaan yang terdaftar dalam indeks LQ 45 periode 2015-2019.

\section{DAFTAR PUSTAKA}

Andre, Orina; Salma Taqwa. 2014. "Pengaruh Profitabilitas, Likuiditas, Dan Leverage Dalam Memprediksi
Financial Distress ( Studi Empiris Pada Perusahaan Aneka Industri Yang Terdaftar Di BEI Tahun 20062010 )." Wahana Riset Akuntansi 2(1): 293-312.

Andriansyah, Muhammad Zulfichrie. 2018. "Pengaruh Rasio Likuiditas, Leverage, Profitabilitas, Aktivitas Dan Pertumbuhan Penjualan Dalam Memprediksi Financial Distress.”

Andyantie, Aldilla. 2018. "Analisis Rasio Keuangan Untuk Memprediksi Kondisi Financial Distress Pada Perusahaan Pertambangan." Jurnal ilmu Dan Riset Manajemen 7(4): 116.

Athaillah. 2018. "Analisis Prediksi Kebangkrutan Perusahaan LQ 45 Menggunakan Metode Z-Score Altman." Center of economic Student Journal 1(1): 29-42.

Atika, Darminto, dan Handayani. 2013. "Pengaruh Beberapa Rasio Keuangan Terhadap Prediksi Kondisi Financial Distress.” Jurnal Administrasi Bisnis 1(2): 10-20.

Chrissentia, Tirza, and Julianti Syarief. 2018. "Analisis Pengaruh Rasio Profitabilitas, Leverage, Likuiditas, Firm Age, Dan Kepemilikan Institusional Terhadap Financial Distress (Pada Perusahaan Jasa Non Keuangan Yang Terdaftar Di Bursa Efek Indonesia Tahun 2014-2016)." SiMAk 16(1): 45-61.

Christine, Debby, Jessica Wijaya, Kevin Chandra, and Mia Pratiwi. 2019. "Pengaruh Profitabilitas, Leverage, Total Arus Kas Dan Ukuran Perusahaan Terhadap Financial Distress Pada Perusahaan Property Dan Real Estate Yang Terdaftar Di Bursa Efek Indonesia Tahun 20142017." Jurnal Ekonomi Dan Ekonomi Syariah 2(2): 340-51. 
Siti Badriyah Islamiyatun, Sri Hermuningsih, Agus Dwi Cahya / Pengaruh Profitabilitas, Likuiditas Dan Solvabilitas Terhadap Kondisi Financial Distress

Desiyanti, Ouw, Wahyoe Soedarmono, Kristian Chandra, and Kusnadi. 2019. "The Effect of Financial Ratios to Financial Distress Using Altman Z-Score Method in Real Estate Companies Listed in Indonesia Stock Exchange Period 2014-2018." Business and Enterpreneurial Review 19(2): 11936.

Erawati, Ruri. 2016. "Pengaruh Likuiditas, Leverage, Profitabilitas, Aktivitas Dan Sales Growth Terhadap Financial Distress."

Erayanti, Rina. 2019. "Pengaruh Likuiditas, Profitabilitas Dan Leverage Terhadap Prediksi Financial Distress." Jurnal Riset Akuntansi dan Perpajakan 6(1): 3851.

Gobenvy, Orchid. 2014. "Pengaruh Profitabilitas, Financial Leverage Dan Ukuran Perusahaan Teradap Financial Distress Pada Perusahaan Manufaktur YangTerdaftar Di Bursa Efek Indonesia Tahun 2009-2011.”

Hapsari, Evanny Indri. 2012. "Kekuatan Rasio Keuangan Dalam Memprediksi Kondisi Financial Distress Perusahaan Manufaktur Di Bei." Jurnal Dinamika Manajemen 3(2): 101-9.

Hardiata, Aktiva Primananda. 2020. Potret Ekonomi Indonesia.

Imam Mas'ud, Reva Maymi Srengga. 2012. "Analisis Rasio Keuangan Untuk Memprediksi Kondisi Financial Distress Perusahaan Manufaktur Yang Terdaftar Di Bursa Efek Indonesia." Jurnal Akuntansi Universitas Jember 10(2): 139-54.

Islami, Imas Nurani dan William Rio. 2018. "Financial Ratio Analysis to Predict Financial Distress on Property and Real Estate Company
Listed in Indonesia Stock Exchange Abstrak." Journal of Applied Accounting and Finance 2(2): 12537.

Khaliq, Ahmad et al. 2014. "Identifying Financial Distress Firms: A Case Study of Malaysia ' s Government Linked Companies ( GLC )." International Journal Of Economics, Finance and Management 3(3): 14150.

Liana, Deny: Sutrisno. 2014. "Analisis Rasio Keuangan Untuk Memprediksi Kondisi Financial Distress Perusahaan Manufaktur." Jurnal Studi Manajemen Dan Bisnis 1(2): 52-62.

Marfungatun, Fitri. 2017. "Pengaruh Rasio Profitabilitas, Likuiditas Dan Leverage Terhadap Kondisi Financial Distress Perusahaan Manufaktur Yang Terdaftar Di Bursa Efek Indonesia." Prodi Akuntansi UPY: 1-12.

Masdupi, Erni, Abel Tasman, and Atri Davista. 2018. "The Influence of Liquidity , Leverage and Profitability on Financial Distress of Listed Manufacturing Companies in Indonesia." Advances in Economics, Business and Management Research 57(Piceeba): 223-28.

Masitoh, Siti; Iwan Setiadi. 2017. "Pengaruh Likuiditas, Profitabilitas, Dan Leverage Terhadap Financial Distress (Pada Perusahaan Jasa Sub Sektor Transportasi Yang Terdaftar Di Bursa Efek Indonesia Periode 2014-2017)." Competitive Jurnal Akuntansi dan Keuangan 4(1): 2536.

Maulina, Rina, Milla Alsura Murtadha. 2019. "Pengaruh Profitabilitas Terhadap Financial Distressdan Dampaknya Terhadap Nilai Perusahaan Pada Perusahaan Sub 
Siti Badriyah Islamiyatun, Sri Hermuningsih, Agus Dwi Cahya / Pengaruh Profitabilitas, Likuiditas Dan Solvabilitas Terhadap Kondisi Financial Distress

Sektor Infrastruktur, Utilitas, Transportasi Yang Terdaftar Di Bursa Efek Indonesia 2011-2015." Akbis: Media Riset Akuntansi dan Bisnis 3(2): 125-32.

Moch, Rusli, Rida Prihatni, and Agung Dharmawan Buchdadi. 2019. "The Effect Of Liquidity , Profitability And Solvability To The Financial Distress Of Manucatured Companies Listed On The Indonesia Stock Exchange ( IDX ) Period Of Year 2015-2017." Academy of Accounting and Financial Studues Journal 23(6): 1-16.

Mudzakar, Mochamad Kohar. 2017. "Implementasi Metode Altman ZScore Untuk Memprediksi Kebangkrutan Perusahaan.” Jurnal Studi Manajemen Dan Bisnis 4(2): 156-66.

Novica Indriaty, Doddy Setiawan, Yuwita Ariessa Pravasanti. 2019. "The Effects Of Financial Ratio, Local Size And Local Status On Financial Distress." International Journal of Economics, Business and Accounting Research 3(1): 38-42.

Qimyatussa'adah, Dian Kusumaningrum. 2019. "Analisis Kebangkrutan Perusahaan Manufaktur LQ 45 Bursa Efek Indonesia.” Jurnal Monex 8(1): 159-68.

Rohmadini, Alfinda, Muhammad Saifi, and Ari Darmawan. 2018. "Pengaruh Profitabilitas, Likuiditas Dan Leverage Terhadap Financial Distress (Studi Pada Perusahaan Food \& Beverage Yang Terdaftar Di Bursa Efek Indonesia Periode 20132016)." Jurnal Administrasi Bisnis 61(2): 11-19.

Septiani, Ni Made Inten dan I Made Dana. 2019. "Pengaruh Likuiditas, Leverage, Dan Kepemilikan Institusional Terhadap Financial
Distress Pada Perusahaan Property Dan Real Estate." E-Jurnal Manajemen 8(5): 3110-37.

Susanti, Neneng, Ifa Latifa, and Denok Sunarsi. 2020. "The Effects of Profitability , Leverage , and Liquidity on Financial Distress on Retail Companies Listed on Indonesian Stock Exchange." Jurnal Ilmiah Ilmu Administrasi Publik 10(1): 45-52.

Tjahjono, Achmad dan Intan Novitasari. 2016. "Analisis Rasio Keuangan Untuk Memprediksi Kondisi Financial Distress Perusahaan Manufaktur Yang Terdaftar Di Bursa Efek Indonesia Tahun 2010-2014." Jurnal Kajian Bisnis 24(2): 131-43.

W.M.H.Nisansala Wijekoon, A.M.I. Lakshan. 2016. "The Use of Financial Ratios in Predicting Corporate Failure in Sri Lanka." GSTF Journal on Business Review (GBR) 2(4).

Wayan, Ni, Krisnayanti Arwinda, Ni Kt, and Lely A Merkusiwati. 2014. "Pengaruh Mekanisme Corporate Governance, Likuiditas, Leverage , Dan Ukuran Perusahaan Pada Financial Distress.” E-Jurnal Akuntansi Universitas Udayana 7(1): 93-106.

Yudiawati, Rike, and Astiwi Indriani. 2016. "Analisis Pengaruh Current Ratio , Debt To Total Asset Ratio , Total Asset Turnover, Dan Sales Growth Ratio Terhadap Kondisi Financial Distress ( Studi Kasus Pada Perusahaan Manufaktur Yang Terdaftar Di BEI Tahun 2012-2014 )." Diponegoro Journal of Management 5(2): 1-13.

Yuliatri, Pratiwi. 2018. "Pengaruh Likuiditas, Solvabilitas, Aktivitas Dan Arus Kas Terhadap Kesehatan Perusahaan (Studi Kasus Pada 
Siti Badriyah Islamiyatun, Sri Hermuningsih, Agus Dwi Cahya / Pengaruh Profitabilitas, Likuiditas Dan Solvabilitas Terhadap Kondisi Financial Distress

Perusahaan LQ 45 Non Perbankan

Yang Tidak Konsisten Yang

Terdaftar Di Bursa Efek Indonesia

2012-2016)."

Zannati, Rachma, and Evita Rosdiana

Dewi. 2019. "Model Prediksi

Financial Distress Perusahaan

Perdagangan Eceran: Pendekatan

Altman Z-Score." Jurnal Riset

Manajemen dan Bisnis 4(3): 469-80. 